\title{
Innovation and entrepreneurship in the HEI sector
}

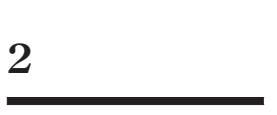

Theoretical background

Why do some individuals become entrepreneurs and others do not? This is one of the most debated questions in the field of entrepreneurship (Paço et al., 2015). In the initial debates, the answer was believed to be because of the existence of some specific personal characteristics in entrepreneurial individuals (Brockhaus, 1980; Carland et al., 1988; Chell and Haworth, 1993). Education plays a critical role in the development of enterprising and innovative citizens, either by identifying and generating aptitudes in individuals or by promoting entrepreneurial intentions (EIs) and behaviors. It can make a big difference to the generation of a new breed of entrepreneurs. This is a belief also shared by politicians and stated, for instance, by the European Union in its Green Paper on entrepreneurship (European Commission, 2003).

The enormous potential of Higher Education Institutions' (HEIs) graduates for innovation and economic development has long been recognized (OECD, 2009; WEF, 2009). Accompanying this recognition of the central role of innovation and entrepreneurship in today's economies has been an added focus on graduate mobility for entrepreneurial careers, entrepreneurial skills and providing for business start-up - all important tasks for HEIs that are only now being entirely recognized (OECD, 2009; WEF, 2009).

In recent years, many countries have pursued a shift beyond the traditional conception that entrepreneurs are born and not made by developing entrepreneurship education (EE). However, an $\mathrm{EE}$ requires a holistic and integrative perspective involving the development of a multi-stage process model that recognizes the key actors, activities and success drivers associated with each stage of the innovation process (Wood, 2011). Neck and Greene (2011, p. 55) present three different approaches used to teach entrepreneurship: the entrepreneur world, the process world and the cognition world. However, entrepreneurship is complex, chaotic and, according to these authors, lack a notion of linearity. They argue that as educators "we have the responsibility to develop the discovery, reasoning, and implementation skills of our students so they may excel in highly uncertain environments."

Accordingly, innovation in EE research involves the development of an encompassing paradigm, appropriate educational methods and study of the institutions that offer the most required incentives (Moroz et al., 2010). Entrepreneurial consciousness education is needed to incentivize students to develop entrepreneurial skills and to support them in choosing a career.

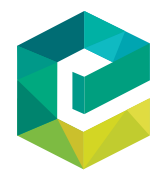

EE ranks high on policy agendas in Europe and the USA, but little research is available to assess its impact. They provide a model of learning in which EE generates signals to students and shows that students receive informative signals and learn about their entrepreneurial aptitude (Graevenitz et al., 2010; Lindh and Thorgren, 2016).

Most university-level programs are intended to increase entrepreneurial consciousness and to prepare aspiring entrepreneurs (Paço et al., 2015). Recent growth in the curricula and programs dedicated to entrepreneurship and new-venture creation has been outstanding (Kuratko, 2005, p. 1) and, according to this argument, while "some legitimacy has been

A sincere word of thanks goes to the team of reviewers for their collaboration and valuable comments. Without their support, it would not have been possible to produce this special issue. 
attained in the current state of EE, there are critical challenges that lie ahead." In this respect, for $\mathrm{EE}$ to embrace the twenty-first century, "professors must become more competent in the use of academic technology and also expand their pedagogies to include new and innovative approaches to the teaching of entrepreneurship" (Kuratko, 2005, p. 591). It is an interesting perspective and certainly a possible way to think about the entrepreneurship field in a different way. The entrepreneur serves as a key element in the process of innovation development and economic growth (Ferreira et al., 2015). Thus, it is crucial that graduate students (as potential entrepreneurs) acquire technical and business skills within their HEI to become successful entrepreneurs in the future.

Entrepreneurship is an economic, social and innovative phenomenon and also an academic and teaching subject. As Drucker (1985, p. 18) argued, "The entrepreneurial mystique? It's not magic, it's not mysterious, and it has nothing to do with the genes. It's a discipline. And, like any discipline, it can be learned".

\section{Contents of this special issue}

The seven papers in this special issue cover a series of inter-related subjects.

The first, titled "Promoting EI through higher education in entrepreneurship and the participation of students in an entrepreneurship ecosystem” by Pilar Fidel, Julia Ferrandiz and Andrea Conchado, attempts to improve the current knowledge of the effects of a higher education program for entrepreneurs, integrated in an entrepreneurial ecosystem, on the EI of students. The authors suggest that the program positively influences students' entrepreneurial intent and, particularly, that working personal skills in the program contributes to the development of their entrepreneurial project.

The second explores the GEM database to identify the key determinants of EI in European countries. The paper, titled "Entrepreneurial intentions and entrepreneurship in Europe countries" by Sérgio Teixeira, Carla Casteleiro, Ricardo Rodrigues and Maria Guerra, shows how the perceived capacity of EI influences the rate of nascent entrepreneurship. Furthermore, governmental and political factors are crucial for research and development.

The third explores the level of EIs among students in three private universities in Bahrain. The paper, titled "Entrepreneurial intention of private university students in the Kingdom of Bahrain" authored by Minwir Al-Shammari and Rana Waleed, examines the factors that are expected to shape EI including personal attraction toward becoming an entrepreneur, perceived behavioral control and subjective norms and social valuation of entrepreneurship.

The fourth sought to evaluate the impact of $\mathrm{EE}$ on the entrepreneurial orientation of higher education students, as mediated by gender and family history. The paper, titled "Entrepreneurship education, gender and family background as antecedents on the entrepreneurial orientation of university students" by Carla Marques, Gina Santos, Anderson Galvão, Carla Mascaranhas and Elsa Justino, argues that EE generally has a greater impact on business and social sciences students. Family background and gender are moderating variables with a positive influence on individual entrepreneurial orientation.

The fifth establishes a model of maturity for the measurement of the level of academic entrepreneurship in universities, and it attempts to apply this model to a sufficiently wide and varied sample of faculties to discover their current level of academic entrepreneurship. This paper, titled "Factors and maturity level of entrepreneurial universities in Spain," is authored by María-José Bezanilla, Nekane Erasti, Ana García-Olalla, Elena Auzmendi and Jessica Paños. The authors provide an innovative model that explains the factors that define 
IJIS

10,1

the entrepreneurial university, as well as guidelines for universities to move forward in further developing stages.

The sixth advances the common domain of EI among academics from different fields of university knowledge and evaluates the effect of entrepreneurial education on students taking management, engineering and accounting courses. The paper, titled "Entrepreneurial intention and the effects of entrepreneurial education: differences among management, engineering, and accounting students" authored by Diego Passoni and Rafael Glavam, shows that entrepreneurial education has a positive effect on EI among undergraduate management and engineering students. According to the authors, this study may encourage investment in entrepreneurial education programs in certain fields of knowledge within institutions and communities that need to foster entrepreneurship as a driver of economic development.

Finally, the seventh proposes to help resolve the question of how universities possessing strategic entrepreneurship manage to advance significantly in their global ranking positions, while most of their competitors fail. The paper, titled "Strategic entrepreneurship based model of latecomer university," authored by Mikhail Kozlov, shows that the presence of strategic entrepreneurship construct dimensions in latecomer university is instrumental in sensing business opportunities in most lucrative market segments of scientific research.

\section{Conclusion and future agenda}

The objective of this special issue was to bring together recent developments and methodological contributions within this field, with the challenges that characterize innovation and entrepreneurship in the HEI sector. Mostly, the papers in this issue contribute to a better understanding of this topic. A wide-ranging thematic analysis underlying innovation and entrepreneurship in HEI is advanced in this special issue.

The papers included in this issue suggest some "hot topics" for future consideration and are summarized as follows:

- analyzing models of the relationship between the influence of methodologies and entrepreneurial skills on the EI of students;

- addressing methodological problems of distinguishing the effect of EIs from other factors that can influence entrepreneurial attitudes;

- examining whether intentions lead to entrepreneurial behavior - like starting up a business - and entrepreneurial success;

- assessing whether various entrepreneurial programs and supports offered by public HEIs and government improve their effectiveness;

- developing studies of EE programs involving professors, local governments and companies to adjust these programs to meet the real needs of the organizations; and

- exploring the measurement of knowledge transfer and its impact on economic and social development.

These findings have particular relevance for policymakers, business organizations and HEIs. They also have wider implications for the development of entrepreneurial policies in different cross-national contexts. To include educational and training elements in entrepreneurial support programs is fundamental to boosting the innovation level and, consequently, greater entrepreneurship development. 
We expect that this special issue will lead the way for more research about this matter, mainly from a multilevel approach. There are several challenges not included here and they merit future examination.

\section{References}

Brockhaus, R.H. (1980), "Risk taking propensity of entrepreneurs", Academy of Management Journal, Vol. 23 No. 3, pp. 509-520.

Carland, J.W., Hoy, F. and Carland, J.A. (1988), "Who is the entrepreneur? Is question worth asking", American Journal of Small Business, Spring, Vol. 12 No. 4, pp. 33-39.

Chell, E. and Haworth, J. (1993), "Profiling entrepreneurs: multiple perspectives and consequent methodological considerations", in Klandt, H. (Ed.), Entrepreneurship and Business Development, Avebury, Aldershot, pp. 251-260.

Drucker, P.F. (1985), Innovation and Entrepreneurship, Harper and Row, New York, NY.

European Commission (2003), Green paper entrepreneurship in Europe, Brussels, 21.01.2003, COM (2003) 27 final, available at: http://ec.europa.eu/invest-in-research/pdf/download_en/ entrepreneurship_europe.pdf

Ferreira, J., Fernandes, C., Alves, H. and Raposo, M. (2015), "Drivers of innovation strategies: testing the Tidd and Bessant (2009) model”, Journal of Business Research, Vol. 68 No. 7, pp. 1395-1403.

Graevenitz, G., Harhoff, D. and Weber, R. (2010), “The effects of entrepreneurship education”, Journal of Economic Behavior \& Organization, Vol. 76 No. 1, pp. 90-112.

Kuratko, D. (2005), "The emergence of entrepreneurship education: development, trends, and challenges", Entrepreneurship Theory and Practice, Vol. 29 No. 5, pp. 577-598.

Lindh, I. and Thorgren, S. (2016), "Entrepreneurship education: the role of local business", Entrepreneurship \& Reginal Development, Vol. 28 Nos 85/86, pp. 313-336.

Moroz, P., Hindle, K. and Anderson, R. (2010), "Collaboration with entrepreneurship education programmes: building spinout capacity at universities", International Journal of Innovation and Learning, Vol. 7 No. 3, pp. 245-273.

Neck, H.M. and Greene, P.G. (2011), "Entrepreneurship education: known worlds and new frontiers", Journal of Small Business Management, Vol. 49 No. 1, pp. 55-70.

OECD (2009), Universities, Innovation and Entrepreneurship Criteria and Examples of Good Practice, OECD, Berlin.

Paço, A., Ferreira, J., Raposo, M., Rodrigues, R. and Dinis, A. (2015), "Entrepreneurial intentions: is education enough?", International Entrepreneurship and Management Journal, Vol. 11 No. 1, pp. 57-75.

WEF (2009), Educating the Next Wave of Entrepreneurs: Unlocking Entrepreneurial Capabilities to Meet the Challenges of the 21st Century, World Economic Forum, Geneva.

Wood, M.S. (2011), “A process model of academic entrepreneurship”, Business Horizons, Vol. 54 No. 2, pp. 153-161. 